\title{
The Effect of Learning Media Utilization to Improve Students' Learning Motivation on Islamic Education Subject in SMA Dharma Wanita 4 Taman Sidoarjo
}

\author{
Nur Chomariah \\ SMA Dharma Wanita 4 Taman Sidoarjo \\ Nurqomariyah51@gmail.com
}

\begin{abstract}
Nur Chomariah, (2017), "The Effect of Learning Media Utilization to Improve Students' Learning Motivation on Islamic Education Subject in SMA Dharma Wanita 4 Taman Sidoarjo".
\end{abstract}

Keywords: Media, Learning, Motivation

Learning media is an important element in teaching and learning process, because it can be loaded messages to be delivered to students either in the form of tools or teaching materials. In addition it is a way to motivate and communicate with students to be more effective, spirit, and enthusiasm in learning activities. Therefore the use of instructional media is needed. This study consists of several problems formulation, such as how the use of media, how the constraints of media use, and how to overcome these obstacles.

Type of research in this thesis used qualitative approach. The data collection technique used observation, interview and documentation. While processing and analyzing the data using data which is obtained from the observation, interview, written footage of the documentary, field notes, which is not written in statistical numbers.

The research findings in this thesis can be concluded: First: Based on the results of the research showed that by using LKS and LCD projector learning media can improve students' learning motivation on learning Islamic Education in SMA Dharma Wanita 4 Taman Sidoarjo. Second: The constraints that researchers found while using LKS media and LCD Projector on learning Islamic Education in SMA Dharma Wanita 4 
Taman Sidoarjo as follows: Unready students in following the lesson at the first meeting by using LKS media, there are students who forget to bring LKS. Third: The efforts which are undertaken as follows: Motivate students to keep the spirit in following the teaching and learning process, advise students to bring their LKS and do not forget it.

\section{A. INTRODUCTION}

Education is essentially a process of knowledge transformation towards improvement, strengthening and perfecting all human potential. Therefore, education does not recognize space and time, it is not limited by the thick walls of the school and also the limited time of study in the classroom. It lasts throughout life and can be done anywhere and anytime the human being wants and able to do the educational process.

In the perspective of Islam, the process of education is often associated with the process of seeking knowledge by humans. Science as a product of the educational process is a means to express, overcome, solve and answer the various problems faced and that will be faced by humans.

Islamic education is an education aimed at forming a full-fledged Muslim person, developing all human potential in both physical and spiritual form, fostering a harmonious relationship of each individual with God, man, and the universe. In order to accomplish that goal, human must have two basic requirements as well they are scientific and morals. ${ }^{1}$

Basically the purpose of Islamic education is to form learners who have noble ethic, as a form of belief in Allah SWT and its form of obedience to the Islamic law. There are two functions of Islamic education. First, Islamic Education is used as a medium to inherit and maintain the culture and ideals of Islamic society. Second, Islamic education serves as an educational activity to equip learners with science in

1 Dauly,Haidar Putra, Pendidikan Islam dalam Mencerdaskan Bangsa( Jakarta: Rineka Cipta, 2012),4. 
accordance with the teachings of Islam as a provision to face the present and the future. $^{2}$

The education and teaching problems are fairly complex problems in which teachers become a very important component in learning activities. Teacher's job is to deliver the subject matter to the students through communication interaction in teaching and learning process that he/she did. The success of the teacher in delivering the material is highly dependent on the smooth communication interaction between the teacher and his/her students. Inaccessibility in communication brings consequences to the messages or metrics delivered by the teacher. ${ }^{3}$

In teaching-learning activities, teachers try to convey something called "message". Conversely, in the learning activities students are also trying to get something. The message or something can be in the form of knowledge, insight, skill, or other teaching such as art, morals, and religion.

In essence the process of teaching-learning is a process of communication between teachers and students, this communication process is realized through communicating and exchanging the messages and information between teachers and students. In order to make the messages or information can be absorbed and understood easily by students, it is required means of communication. The means or tools used to facilitate communication in teaching and learning process is called as learning media.

Students who learn will experience change. For example, the ability is only $35 \%$ before learning, then after learning for five months it will increase $100 \%$. These learning outcomes improve mental ability. In general, these learning outcomes include cognitive, affective, and psychomotor aspects.

Ability to be achieved in learning is the goal of learning. There is a gap between pre-learning ability and ability to be achieved. The gap can be overcome due to learning the specific teaching materials. ${ }^{4}$

2 Ibid,4.

3 Asnawir dan Basyiruddin Usman, Media Pembelajaran (Jakarta: Ciputat Pers, 2002 ), 1.

4 Dimyati dan Mudjiono, Belajar dan Pembelajaran (Jakarta:PT Rineka Cipta, 2006), 174. 
The development of science and technology increasingly encourage renewal effort in the utilization of technological results in the learning process. Teachers are required to be able to use the tools that can be provided by the school, and it is not possible that the tools are in accordance with the development and demands of the times. $^{5}$

Learning media is an important element in teaching and learning process, because it can be loaded messages to be delivered to students either in the form of tools or teaching materials. In addition learning is one way to motivate and communicate with students to be more effective, spirit, and enthusiasm in learning activities. Therefore the use of instructional media is needed.

Effective learning requires good planning. The media that will be used in the learning process also requires good planning. Nevertheless, the reality on the ground shows that a teacher chooses one medium in his/her class activities based on considerations including: (a) he/she feels familiar with whiteboard or projector media, (b) he/she feels that the media that he/she already chosen can describes better than himself/herself - for example, a chart on a flip chart, or (c) the media that he/she chooses can attract students' interest and attention, and also be able to guide to a more structured and organized presentation. This consideration is expected by the teacher to meet his/her needs in achieving the goals that he/she has set. ${ }^{6}$

In general, the position of Learning Media serves as an intermediary or a means of managing messages in learning activities that provide stimulus to students so that students can understand the material explained by the teacher, from the abstract into a more concrete concept. A person's attitude and behavior will change. A change after they gain new knowledge and experience. The use of media in PAI learning will help students acquire new knowledge and experience through material which is presented by teachers compared with verbal approach from teacher. ${ }^{7}$

5 Arsyad Azhar, Media Pembelajaran(Jakarta:Rajawali Pers, 2010), 2.

6 Azhar Arsyad, Media Pembelajaran(Jakarta: PT RajaGrafindo Persada,2014), 67.

7 Muhaimin,dkk, Paradigma Pendidikan Islam Upaya Mengefektifkan Pendidikan Agama Islam di Sekolah (Bandung: PT Rosdakarya, 2002), 200. 
The use of instructional media as a learning resource used systematically in the learning activities will be able to provide interaction between new experiences and previous experiences, so that there is a change in students' behavior.

\section{B. Research Focus}

To facilitate the discussion of this scientific paper it is necessary to point out the formulation of the problem, as follows:

1. How is the use of instructional media to improve students' learning motivation on PAI subjects in Dharma Wanita High School 4 Kec. Taman Sidoarjo?

2. How to constrain the use of learning media to improve students' learning motivation on PAI subjects in Dharma Wanita High School 4 Kec. Taman Sidoarjo?

3. How to overcome the obstacles of the use of learning media to improve students' learning motivation on PAI subject in Dharma Wanita High School 4 Kec. Taman Sidoarjo?

\section{Research Methods}

This research is adapted to the problems above, so this research is descriptive qualitative research. Bodgan Taylor defined a qualitative method as a research procedure that produces descriptive data in the form of written or oral words of observable behavioral persons. According to them this approach is directed at the background and the individual holistically (whole). ${ }^{8}$ In qualitative research, the theory is limited to a systematic sense or question that deals with a set of propositions derived from empirically reinterpreted data. ${ }^{9}$

Qualitative research obtains data in the form of words, behavior and the rest is additional data such as documents and others. The observed, interviewed and

8Lexy, J, Meolong, Metode Penelitian Kualitatif(Bandung: Remaja Rosda Karya, 2004), 3

9/bid.,8 
documented words and behaviors are the primary source and recorded through written notes or through video recording or audio tape, photo capture, or film. ${ }^{10}$

In descriptive research, the data collected are not in numbers or figures. Such data may be derived from interviews, field notes, photographs, tape recorders, notes or memos or other documents. This study is adapted to the problems that researchers take using a qualitative approach. In qualitative research, theory is limited to the sense of a systematic question pertaining to a set of propositions which is derived from empirically tested data. Qualitative research itself is a research approach that comes from the observation of the research object. ${ }^{11}$ This research is more analytically descriptive which is trying to describe or analyze the effective media in learning Islamic Education in Taman Sidoarjo and how is the use of instructional media to improve students' learning motivation on Islamic Education subject in Taman Sidoarjo.

According to Suryabrata, descriptive research is "research that intends to make description about the situations or events". ${ }^{12}$ While the purpose of descriptive research according to Amiruddin is: to describe the exact nature of an individual, the circumstances, the symptoms, or to determine the least relationship between a symptom with other symptoms in society. ${ }^{13}$

\section{Discussion of Research Results}

The effect of Learning Media Utilization to Improve Students' Motivation on Islamic Education Subject in SMA Dharma Wanita 4 Taman Sidoarjo.

The background behind the use of learning media on Islamic Education in SMA Dharma Wanita 4 Taman Sidoarjo, is to improve students' motivation on

10Nasution, Metode Penelitian Naturalistik Kualitatif (Bandung: Transito, 1988), 112

11Lexy J. Moleong, Metodelogi Penelitian Kualitatif (Bandung: PT Remaja Rosdakarya, 2002), 2

12Sumadi suryabrata, Metodelogi Penelitian (Jakarta: PT. Raja Grafindo Persada, 1998), 18

13 Amiruddin dan Zainal Asikin, Pengantar Metode Penelitian Hukum (Jakarta: Raja Grafindo Persada, 2004), 25 
Islamic Education subject. Therefore, students in SMA Dharma Wanita 4 Taman Sidoarjo are less motivated when they follow the lesson of Islamic Education subject. Students' interest in the Islamic Education subject is still minimal although they are in a fairly active class in learning. Therefore, to overcome this problem, it is necessary to conduct research to improve the Islamic Education Learning in SMA Dharma Wanita 4 Taman Sidoarjo, so that the purpose of Islamic Education can be achieved.

Because Islamic Education in school is aimed to grow, improve faith virtue, has a good attitude, and able to fight to uphold the values of Islam in the society through the provision of knowledge to learners in accordance with the principles and concepts of Islam in realizing religious values as the achievement foundation of national education objectives.

To realize the goal of Islamic Education Learning as mentioned above, one of the things that need to be done by teachers is to do various development and learning approach so that students are motivated, high learning motivation and good achievement. The way that can stimulate and can provoke students to have high motivation of learning is to use learning media or educational media.

The use of LKS and LCD Projectors learning media on Islamic education subject is expected to generate interest and new stimulation on students to learn. Due to the use of the right media can facilitate students in understanding the content of the subject matter.

As for the use of LKS media, students can learn anytime, they do not need to write what is explained by the teacher, they can learn at their home, they can practice to do the exercise in their own LKS. Whereas by using the LCD projector media with the help of Microsoft Power Point program in computer, they can see the views, such as pictures, writings and they can write a summary from the material that is made by the teacher using Power Point.

Actually the use of LKS media in SMA Dharma Wanita 4 Taman is not an odd, the teacher of Islamic Education in that school has often used it, but the students are less enthusiastic and less motivated because the teacher is less concerned about their understanding so that they are bored, lazy and sleepy when they took Islamic education subject. Because of that problem the researcher tries to keep using the LKS 
media with different methods that involve students in teaching and learning activities by inviting them to discuss, try to understand the text in the LKS, and they try to explain and ask about the meaning of the text with their own language, and in the end of the lesson the researcher will assign the tasks which is already exist in their own LKS.

In using the LCD projector media, a teacher is required to create creative designs or display images, writing using the power point, because it can stimulate and bring new passion to them so that they are more motivated in teaching and learning activities.

Based on the results of research that has been done before and after using LKS media and LCD Projector, it showed significant learning, where the students' motivation in following the lesson is very good, they are active and courageous in expressing their opinion, and their learning outcomes are good. This cannot be separated from the teachers' performance that must be able to make arrangements, the use of media well and precisely and also the evaluation system is done.

Mr Abdul Munif said:

"The use of LKS media by involving students in learning such as discussion, questioning, giving the task to make students do not feel sleepy and lazy, especially by using LCD projector media they even more excited and their motivation more focused when they listened to the teachers' explanation". ${ }^{14}$

In this observation, during the implementation of classroom learning by using LKS media, understanding the material, discussing it, and assigning tasks at the end of the lesson, it appears that the students are getting enthusiastic and responding positively. There is an increase in learning motivation which is compared to pretest. This can be seen from the students' curiosity about the content of the material in LKS by integrating their understanding with their group, they like to ask if their understanding is not the same as their friends. This is very different, in the pre-test they are mostly silent, sleeping, and a little of them ask question. On this observation they have begun to be motivated though not all of them.

During the course, the researcher acts as a teacher as well as an observer who notes the observation sheet on the observation guidelines. Observations at the 
introduction stage, lack response of the students and they are not motivated, this is due to they have not received a refresher in teaching and learning activities, so they try to focus their attention during the learning takes place. However, when entering the material explanation globally, there are some students who ask questions though less good. This is because they are not used to ask questions. Instead, they prefer to answer questions.

Entering the core activity stage, they quickly discussed and understood the material in the LKS with their respective groups. In the first meeting, group one and two with representatives explain the contents of the material in the LKS in accordance with their understanding. Likewise at the next meeting the teacher should give the students' time to understand and discussed, after which group three and four explain the results of the discussions that have been discussed.

After they have finished trying to explain the results of their discussion and understanding, the researcher tries to answer the unanswered questions or has not been able to satisfy the questioning group, and the researcher also gives opportunity to the students to ask about the unfamiliar material in LKS. After no questions from the students the researcher gave the homework in the LKS with the material which is already discussed. In this study, researcher trains students to be active and courageous to express their opinions with the material which is already exist in the LKS.

Based on the observation result, it is known that students have started enthusiastic in following the learning process, they have started to be motivated, although not all of them as expected. This can be seen from the students' observation sheet which showed that their activity have started to improve from the previous one. Activities to understand the material in the LKS with discussions, express opinions, ask questions and homework is pretty good. Although it still dominated by active students, this is due to individual differences in each student. Those who are active are the majority of those who have achievements in the classroom, and those who are passive are those who have less or moderate achievement and they tend to lack confidence in their abilities.

Furthermore, to find out whether the students have been motivated or not to the material of Islamic Education, the researcher saw the students' enthusiasm when 
following the learning with them who dare to explain the material in the LKS in accordance with their own understanding, the number of students who ask, students do the tasks that have been given by researcher. The observation results showed that students have started to actively follow the lesson, they have begun to dare to ask, they do the assignment that has been given. Indicators of students' motivation improvement in learning are reflected in their spirit, enthusiasm, and curiosity in Teaching and Learning Activities.

\section{E. CONCLUSION}

From the description that has been explained by the researcher, there are some conclusions that can be taken as an answer to the research problems that have been formulated, including:

Based on the research results that has been done showed that by using LKS and LCD projector learning media can improve students' learning motivation on learning Islamic Education in SMA Dharma Wanita 4 Taman Sidoarjo.

Indicators of students' learning motivation improvement can be seen from the increase of their spirit and enthusiasm in learning activities, there is no feeling of laziness and weariness on their faces, they always show happiness and glad during the lesson, they always try to finish the tasks on time, as well as the magnitude of their curiosity which is applied by asking questions if there is material that is poorly understood by them and vying to answer the questions that are given by the researcher.

2. The obstacles in the use of LKS and LCD Projector learning media.

The obstacles that are found by the researchers when using LKS and LCD Projectors media on learning Islamic Education in SMA Dharma Wanita 4 Taman Sidoarjo is the lack of students' readiness in following the lesson at the first meeting using LKS media, so that there was less learning, there are students who forgot to bring LKS, they cannot make power point, so in using LCD projector the researchers use it dominantly, there are students who are late and ask permission when learning takes place, they do not prepare the material before entering the class, so researchers 
should try to maximize and facilitate students in understanding the lesson, the outside environment of the classroom which is busy enough with other class students (because there is an empty class) Out-of-class ethics is very supportive on the learning process.

3. Overcoming the obstacles in using LKS and LCD Projector learning media.

By finding the obstacles above, then the researcher found solutions and minimize it, as for the efforts undertaken is to motivate students to always keep spirit in the learning and teaching process because the material taught is very important in everyday life, suggest to the them to always carry their LKS and do not forget it, in order to convey material they do not need to write. If students do not bring LKS the teacher will give sanction, motivate and suggest them to learn to make Power Point either to teacher or course, so that when they were become university students they do not need to learn anymore, teachers advise to students who do not have class to do not make noisy because it was disturbing their friends' concentration and the teacher also informed the school security authorities. 


\section{BIBLIOGRAPHY}

Al-Qur'an danTerjemahnya, Surabaya: PenerbitMahkota, 1989.

Ahmad Rohani, 1997, Media InstruksionalEdukatif, Jakarta: PT. RinekaCipta.

Amiruddin dan ZainalAsikin, PengantarMetodepenelitianHukum, Jakarta: Raja

GrafindoPersada, 2004.

Arief S. Sadirman, dkk. Media Pendidikan, Jakarta: PT. RajagrafindoPersada, 1986.

Arief S, Media Pengajaran: Pengertian, PengembangandanPemanfaatan, Jakarta: P.T.

RajagrafindoPersada, 2002.

Ashar Arsyad, MA. Media Pembelajaran, Jakarta: PT Rajagrafindo, 2002.

Asnawir dan Basyirudin Usman, Media Pembelajaran, Jakarta: CiputatPers, 2002.

Consuelo G. Sevilla, dkk. PengantarMetodePenelitian, Jakarta: UI Press, 1993.

Dimyati dan Mudjiono, BelajardanPembelajaran, Jakarta: RinekaCipta, 2006.

Muhaimin, dkk. ParadigmaPendidikan Islam UpayaMengefektifkanPendidikan Agama

Islam di Sekolah, Bandung: PT Rosdakarya, 2002.

Muhaimin, Pengembangan Kurikulum Pendidikan Agama Islam, Jakarta: Raja

GrafindoPersada, 2005.

Sugiyono. Metode Penelitian Pendidikan. Bandung: Alfabeta, 2008. . Metode Penelitian Kuantitatif Kualitatif dan R\&D. Cet. ke-6. Bandung:

Alfabeta, 2009.

SantosoSinggih, Buku Latihan SPSS Statistik Parametrik, Jakarta: PT Elex Media Komputindo, 2001.

Arikunto, Suharsimi. Prosedur Penelitian: Suatu Pendekatan Praktik. Jakarta: Rineka Cipta, 2002.

Sugiyono. Metode Penelitian Kuantitatif Kualitatifdan R \& B. Bandung :Alfabeta, 2007. 
